\title{
Gulf of Mexico Science
}

Volume 6

Number 2 Number 2

Article 1

$10-1983$

\section{Macroinvertebrate Infauna of a Salt Marsh Tidal Creek}

Ronald G. Horlick

Florida A\&M University

C.B. Subrahmanyam

Florida A\&M University

Follow this and additional works at: https://aquila.usm.edu/goms

DOI: 10.18785/negs.0602.01

\section{Recommended Citation}

Horlick, R. G. and C. Subrahmanyam. 1983. Macroinvertebrate Infauna of a Salt Marsh Tidal Creek.

Northeast Gulf Science 6 (2).

Retrieved from https://aquila.usm.edu/goms/vol6/iss2/1

This Article is brought to you for free and open access by The Aquila Digital Community. It has been accepted for inclusion in Gulf of Mexico Science by an authorized editor of The Aquila Digital Community. For more information, please contact Joshua.Cromwell@usm.edu. 


\title{
MACROINVERTEBRATE INFAUNA OF A SALT MARSH TIDAL CREEK
}

\author{
Ronald G. Horlick and C.B. Subrahmanyam \\ Salt Marsh Ecology Project \\ Florida A \& M University \\ Tallahassee, FL 32307
}

\begin{abstract}
Tidal creeks are the main avenues for exchange of materials between salt marshes and river mouth estuaries. The spatial and temporal distributions of benthic macroinvertebrate infauna of a tidal creek near St. Marks Lighthouse in northern Florida were investigated. One hundred and eleven species were found during the course of study. The numbers of species and individuals declined from the creek mouth to its origin. The results were compared to published macrobenthic invertebrate data from a nearby estuary and nearby salt marshes to determine the faunal relationships of these areas to the creek. More estuarine species than marsh species were found at the creek mouth but at the creek headwaters fewer estuarine than marsh species were found. However, numerous creek species had not been recorded from local salt marsh or estuarine locations. The evidence indicates this tidal creek to be an ecotone between the salt marsh and the adjoining estuarine habitat.
\end{abstract}

Tidal creeks are integral parts of a salt marsh system and connect it to an adjoining estuary. Various materials are known to be transported in these creeks during tidal cycling (de la Cruz, 1973; Settlemyre and Gardner, 1975; Pickral and Odum, 1976; and Hackney and de la Cruz, 1979). Tidal creeks also act as pathways for fish and invertebrates to travel between marsh and estuary (Subrahmanyam and Drake, 1975; Hackney and Burbanck, 1976; Hackney, Burbanck and Hackney, 1976; Subrahmanyam, Kruczynski and Drake, 1976; Homer, 1977; Hackney and de la Cruz, 1978; Subrahmanyam and Coultas, 1980; and Weinstein, Weiss and Walters, 1980).

Salt marsh invertebrate fauna is composed of both estuarine and resident species (Teal, 1962; Subrahmanyam et al., 1976). Since tidal creeks connect salt marshes to estuaries, it is reasonable to assume that the creek fauna is similar to the fauna of these habitats. What is not known, however, is the relative importance of the salt marsh and estuarine faunal components to a tidal creek as it is traversed from its origins in the marsh to its mouth in the estuary. The present study seeks to determine the spatial and temporal patterns of macrobenthic in. vertebrate infauna at four study sites located along the length of a tidal creek.

\section{MATERIALS AND METHODS}

\section{Study Area}

A tidal creek $11 / 2 \mathrm{~km}$ north of St. Marks Lighthouse $\left(30^{\circ} 5^{\prime} \mathrm{N}, 84^{\circ} 11^{\prime} \mathrm{E}\right)$ was chosen as the study site (Figure 1). Four infaunal sampling stations were established along the length of the creek. The first of these stations was at the creek's mouth and the last at the origin, with the remaining two stations at approximately $100 \mathrm{~m}$ intervals. Spartina alterniflora bordered the creek, and Juncus roemerianus was the dominant halophyte of the adjacent marsh; this vegetational pattern is typical of northern Florida marshes (Eleuterius, 1976). Water depth during an average high tide was about $100 \mathrm{~cm}$ at stations 1 (at the mouth) and 4 (at the origin), 75 $\mathrm{cm}$ at station 2 and $50 \mathrm{~cm}$ at station 3 . During low tide, water depth was $5.10 \mathrm{~cm}$ at stations 1 and 4 , and less than $5 \mathrm{~cm}$ at station 2. Station 3 was completely drained during most low tides.

\section{Sampling Procedure}

The study was conducted from 


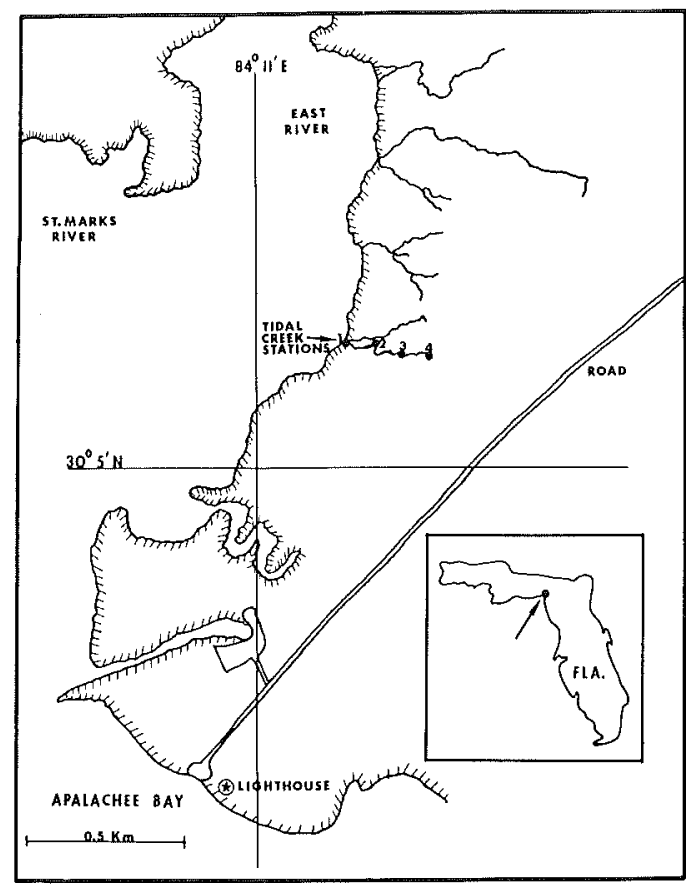

Figure 1. The location of the four stations in a tidal creek in the St. Marks Lighthouse marsh.

January to December, 1977. Initial samples taken during the first two months were used to determine optimum time of sampling, sample size, number of samples, quadrat size and depth of sampling. Thereafter, monthly, triplicate, $15 \mathrm{~cm}$ deep cores were taken randomly during low tide using a $20 \mathrm{~cm}$ long, $6.9 \mathrm{~cm}$ i.d. plexiglass tube, from a gridded site at each station. Samples were sieved in the field using a $0.5 \mathrm{~mm}$ mesh ( 8 " U.S. standard) sieve. The 0.5 $\mathrm{mm}$ mesh size was chosen so that juveniles of some macrofaunal groups could be retained. Meiofauna captured using this sieve is not discussed in this report. Organisms retained on the screen were fixed in the field using buffered $10 \%$ formalin-seawater with rose bengal as a vital dye. In the laboratory, the species were classified and then stored in $40 \%$ isopropyl alcohol. Identifications of macrofauna were done to the species level where possible with the exception of the oligochaetes which were treated as a single taxon.

\section{Calculations and Statistics}

Distributional statistics, including number of species, number of individuals $/ \mathrm{m}^{2}$, rank by number and percent of total were evaluated for each station. Density $/ \mathrm{m}^{2}$ was computed by multiplying the average number of animals collected in the three replicate cores by 89 . Biological importance (Sanders, 1960) was calculated for each station.

Differences in faunal diversity and affinity were used to support observations of distributional trends. ShannonWeaver's $\mathrm{H}^{\prime}$ with Basharin's (1969) correction for sample size was used as the index of diversity. Morisita's Index of Affinity $(C \lambda)$ (Morisita, 1959) was calculated to determine the similarity of species composition between stations. Analysis of variance (ANOVA) and Duncan's New Multiple Range Test (DNMRT) (Steele and Torrie, 1960) were used to test the significant differences of $\mathrm{H}^{\prime}$ among stations, and to evaluate spatial and temporal changes in the numerical abundance and numbers of species found at the four stations.

\section{RESULTS}

A total of 111 species with 7,579 individuals was recorded during this study. These were distributed among the stations as follows: station 1, 78 species (2,602 individuals); station 2, 66 species (1,924 individuals); station 3, 54 species (1,362 individuals); and station 4, 44 species (1,691 individuals) (Table 1).

The densities of organisms at all stations varied both spatially and temporally with a high of $43,343 / \mathrm{m}^{2}$ at station 1 in March and a low of $979 / \mathrm{m}^{2}$ at station 3 in August. The greatest number of individuals was usually taken at station 1, and a more or less step-wise decline in densities was observed 
through the remaining stations. Seasonal fluctuation patterns in density tended to be similar at all four stations. Densities peaked at stations 1,2 and 3 in March, followed by a drop at all stations during July and August, then rose for the most part during September, and generally decreased again during November and December (Figure 2). The density increases, although similar at all stations, were largely due to different species at each station. A large elevation during spring at station 1 was mostly due to an increase in populations of the amphipod Ampelisca abdita and the tanaidacean Hargaria rapax. The fall peak at station 1, however, was predominantly due to high abundance of the polychaete Laeonereis culveri along with $H$. rapax. Peaks at stations 2 and 3 were greatly due to an increase of the gastropod Hydrobia sp., while $H$. rapax and the polychaete Fabricia $s p$. were largely responsible for the spring peak at station 4 . These differences in monthly densities among stations were found to be significant from stations 3 and 4 , and station 3 was significantly different from station 4 (DNMRT, $p<0.05$ ).

Seasonal trends in number of species at each station closely paralleled those of density. The station 3 sample in August with three species had the lowest number of species of any sample. This corresponded to the lowest density which also occurred at station 3 in August. The highest number of species, however, was concurrent with the third highest density value. Station 1 , with 40 species and station 2 , with 47 species showed their greatest numbers of species in June while station 3, with 25 species, peaked in March and station 4, had a high of 19 species in March and then again in May. All of the stations showed their lowest numbers of species during July and August with a second low in November (Figure 2). Differences in species numbers among stations were found to be significant (ANOVA, $p<0.05$ ). Station 1 was found to be significantly different in numbers of species from stations 2, 3 and 4; station 2 was significantly different from stations 3 and 4 ; but station 3 was not significantly different from station 4 (DNMRT, $p<0.05$ ).

A gradient was detected when we considered the number of species, enumerated from the most numerous to the least numerous, needed to account for $90 \%$ of the density at each station. At station 1, the most estuarine of the stations, 21 species were needed to make up $90 \%$ of the total density while 13 species were required at stations 2 and 3 and only 5 species at station 4 (Table 1). Hargaria rapax, Laeonereis culveri and the gastropod hydrobid sp. 1 were the only species found to be in common from the top $90 \%$ of the species at all stations. Other species were found to be important at one, two or three stations but not at the others. Ampelisca abdita was the most abundant species at station 1 but occurred in low numbers at stations 2, 3, and not at all at station 4. The polychaete Streblospio benedicti was found to be equally important at stations 1, 2 and 3. The isopod Xenanthura brevitelson and the polychaetes Aricidea sp., Amphicteis gunneri and Sphaerosyllis longicirrata were important only at stations 1 and 2. The amphipod Grandidierella bonnieroides, the isopod Edotea montosa and the polychaete Haploscoloplos foliosus were important at stations 1 and 3 but not at 2 or 4 . The cumacean Almyracuma sp. and the gastropod Parastarte triquetra were important at stations 2 and 3 but not at 1 or 4. The polychaete Fabricia sp. was very abundant at station 4 but found only rarely at the other stations.

There were wide seasonal and 
Table 1. Distributional statistics of all species found at the four St. Marks tidal creek stations including the total number of species, rank by number and rank by percentage at each site.

\begin{tabular}{|c|c|c|c|c|c|c|c|c|c|c|c|c|}
\hline \multirow[t]{2}{*}{ Species } & \multicolumn{3}{|c|}{ Station 1} & \multicolumn{3}{|c|}{ Station 2} & \multicolumn{3}{|c|}{ Station 3} & \multicolumn{3}{|c|}{ Station 4} \\
\hline & $\begin{array}{l}\text { \# of } \\
\text { Ind. }\end{array}$ & $\begin{array}{c}\text { Rank } \\
\text { by \# }\end{array}$ & $\begin{array}{l}\% \text { of } \\
\text { total }\end{array}$ & $\begin{array}{l}\text { \# of } \\
\text { Ind. }\end{array}$ & $\begin{array}{l}\text { Rank } \\
\text { by \# }\end{array}$ & $\begin{array}{l}\% \text { of } \\
\text { total }\end{array}$ & $\begin{array}{l}\text { \# of } \\
\text { Ind. }\end{array}$ & $\begin{array}{c}\text { Rank } \\
\text { by \# }\end{array}$ & $\begin{array}{l}\% \text { of } \\
\text { total }\end{array}$ & $\begin{array}{l}\text { \# of } \\
\text { Ind. }\end{array}$ & $\begin{array}{l}\text { Rank } \\
\text { by \# }\end{array}$ & $\begin{array}{l}\% \text { of } \\
\text { total }\end{array}$ \\
\hline Ampelisca abdita & 641 & 1 & 24.63 & 32 & 14 & 1.66 & 11 & 14 & 0.81 & 2 & 23 & 0.12 \\
\hline Hargaria rapax ${ }^{+\star}$ & 279 & 2 & 10.72 & 75 & 10 & 3.89 & 13 & 12 & 0.95 & 366 & 2 & 21.64 \\
\hline oligochaetes & 242 & 3 & 9.30 & 218 & 3 & 11.30 & 147 & 3 & 10.79 & 765 & 1 & 45.24 \\
\hline Aricidea sp. & 240 & 4 & 9.22 & 108 & 6 & 5.30 & 1 & 37 & 2.79 & & & \\
\hline Laeonereis culverit & 237 & 5 & 9.11 & 322 & 1 & 16.69 & 196 & 2 & 14.39 & 137 & 4 & 8.10 \\
\hline Xenanthura brevite/son ${ }^{+}$ & 129 & 6 & 4.96 & 144 & 4 & 7.47 & 3 & 22 & 0.22 & 4 & 19 & 0.24 \\
\hline Gammarus mucronatus ${ }^{+\star}$ & 87 & 7 & 3.34 & 18 & 17 & 0.93 & & & & & & \\
\hline Amphicteis gunnerit ${ }^{+\star}$ & 66 & 8 & 2.54 & 15 & 18 & 0.78 & 5 & 17 & 0.38 & & & \\
\hline Grand/dierella bonnieroldes ${ }^{+\star}$ & 64 & 9 & 2.46 & 22 & 16 & 1.14 & 16 & 11 & 1.17 & & & \\
\hline Sphaerosyllis longicirrata & 55 & 10 & 2.11 & 41 & 12 & 2.13 & 2 & 27 & 0.15 & & & \\
\hline Haploscoloplos follosus & 46 & 11 & 1.77 & 86 & 8 & 4.46 & 69 & 5 & 5.07 & 10 & 11 & 0.60 \\
\hline Streblospio benedicti ${ }^{*}$ & 42 & 12 & 1.61 & 36 & 13 & 1.87 & 36 & 6 & 2.64 & & & \\
\hline hydrobid \#1 & 35 & 13 & 1.35 & 281 & 2 & 14.57 & 575 & 1 & 42.22 & 38 & 5 & 2.25 \\
\hline chironomid larvae & 35 & 14 & 1.35 & 26 & 15 & 1.35 & 8 & 15 & 0.59 & 6 & 16 & 0.35 \\
\hline Melinna maculata ${ }^{+}$ & 35 & 15 & 1.35 & 8 & 23 & 0.41 & 1 & 38 & 0.07 & & & \\
\hline Ampelisca verrilli $i^{+}$ & 32 & 16 & 1.23 & 6 & 28 & 0.31 & 3 & 23 & 0.22 & & & \\
\hline Bittium varium ${ }^{*}$ & 24 & 17 & 0.92 & & & & & & & & & \\
\hline nemertine \#1 & 23 & 18 & 0.88 & 13 & 21 & 0.67 & 24 & 9 & 0.67 & 1 & 27 & 0.06 \\
\hline Cymadusa compta & 20 & 19 & 0.77 & 4 & 31 & 0.21 & & & & 1 & 28 & 0.06 \\
\hline Edotea montosa ${ }^{+}$ & 19 & 20 & 0.73 & 7 & 25 & 0.36 & 25 & 8 & 1.84 & 1 & 29 & 0.06 \\
\hline Polydora $/ \operatorname{lgn} I^{+}$ & 19 & 21 & 0.73 & 14 & 20 & 0.73 & & & & 1 & 30 & 0.06 \\
\hline Retusa canaliculata ${ }^{+}$ & 16 & 22 & 0.61 & 5 & 30 & 0.26 & 1 & 39 & 0.07 & & & \\
\hline Almyracuma sp. & 14 & 23 & 0.54 & 87 & 7 & 4.51 & 93 & 4 & 6.83 & 4 & 20 & 0.23 \\
\hline Parastarte triquetra & 14 & 24 & 0.54 & 79 & 9 & 4.10 & 30 & 7 & 2.20 & 10 & 12 & 0.59 \\
\hline Mysella planulata & 13 & 25 & 0.50 & 2 & 35 & 0.10 & 2 & 28 & 0.15 & & & \\
\hline Eriahsonella attenuata & 12 & 26 & 0.46 & 8 & 24 & 0.41 & & & & & & \\
\hline nemertine \#2 & 10 & 27 & 0.38 & 7 & 26 & 0.36 & 5 & 18 & 0.37 & 2 & 24 & 0.12 \\
\hline Amygdalum papyria ${ }^{+}$ & 10 & 28 & 0.38 & 2 & 36 & 0.10 & 1 & 40 & 0.07 & 3 & 21 & 0.18 \\
\hline Taphromysis bowmani ${ }^{+}$ & 9 & 29 & 0.35 & 4 & 32 & 0.21 & & & & & & \\
\hline nemertine \#3 & 9 & 30 & 0.35 & 2 & 37 & 0.10 & 2 & 29 & 0.15 & & & \\
\hline Fabricia $s p .^{+}$ & 8 & 31 & 0.31 & 1 & 44 & 0.05 & 2 & 30 & 0.15 & 206 & 3 & 12.18 \\
\hline Cerithidea scalariformis ${ }^{*}$ & 8 & 32 & 0.31 & 1 & 45 & 0.05 & 3 & 24 & 0.22 & & & \\
\hline Cerapus estuarlus & 7 & 33 & 0.27 & & & & & & & & & \\
\hline Littorina Irrorata* & 6 & 34 & 0.23 & 125 & 5 & 6.48 & 1 & 41 & 0.07 & 1 & 31 & 0.06 \\
\hline Heteromastus filiformis ${ }^{+}$ & 6 & 35 & 0.23 & 10 & 22 & 0.52 & 23 & 10 & 1.69 & & & \\
\hline Lyonsla hyalina* & 6 & 36 & 0.23 & 1 & 46 & 0.05 & 1 & 42 & 0.07 & & & \\
\hline Glyoera americana & 6 & 37 & 0.23 & 1 & 47 & 0.05 & 1 & 43 & 0.07 & & & \\
\hline Ampellsca vadorum ${ }^{+}$ & 5 & 38 & 0.18 & 2 & 38 & 0.10 & & & & & & \\
\hline Cymodoce faxoni & 5 & 39 & 0.18 & 1 & 48 & 0.05 & & & & & & \\
\hline Cerapus $s p .^{+}$ & 5 & 40 & 0.18 & & & & & & & & & \\
\hline Cyclaspis sp. & 5 & 41 & 0.18 & & & & & & & & & \\
\hline Eteone heteropoda ${ }^{+*}$ & 3 & 42 & 0.12 & 6 & 29 & 0.31 & 5 & 19 & 0.37 & 2 & 25 & 0.12 \\
\hline Macoma constricta & 3 & 43 & 0.12 & 1 & 49 & 0.05 & 4 & 20 & 0.29 & 1 & 32 & 0.06 \\
\hline turbellarian \#2 & 3 & 44 & 0.12 & & & & 3 & 25 & 0.22 & & & \\
\hline Nereis succinea ${ }^{+*}$ & 3 & 45 & 0.12 & & & & 2 & 31 & 0.15 & 1 & 33 & 0.06 \\
\hline slpunculld \#2 & 3 & 46 & 0.12 & & & & 2 & 44 & 0.15 & & & \\
\hline Oxyurosty/is smithl & 3 & 47 & 0.12 & & & & & & & & & \\
\hline Amphipholes sp. & 3 & 48 & 0.12 & & & & & & & & & \\
\hline Mitrella lunata ${ }^{+}$ & 3 & 49 & 0.12 & & & & & & & & & \\
\hline Tagelus plebius ${ }^{+}$ & 2 & 50 & 0.08 & 15 & 19 & 0.74 & 2 & 32 & 0.15 & 2 & 26 & 0.12 \\
\hline hydrobld \#2 & 2 & 51 & 0.08 & 1 & 50 & 0.65 & 8 & 16 & 0.59 & 8 & 13 & 0.48 \\
\hline mite & 2 & 52 & 0.08 & 3 & 34 & 0.16 & & & & 7 & 14 & 0.41 \\
\hline Monoculodes edwardsi & 2 & 53 & 0.08 & 1 & 51 & 0.05 & & & & & & \\
\hline Anomalocardia cunemeris & 2 & 54 & 0.08 & 1 & 52 & 0.05 & & & & & & \\
\hline Capittela capitata ${ }^{+}$ & 1 & 55 & 0.04 & 1 & 53 & 0.05 & 12 & 13 & 0.88 & 17 & 7 & 1.01 \\
\hline
\end{tabular}


Table 1. Continued.

\begin{tabular}{|c|c|c|c|c|c|c|c|c|c|c|c|c|}
\hline \multirow[t]{2}{*}{ Species } & \multicolumn{3}{|c|}{ Station 1} & \multicolumn{3}{|c|}{ Station 2} & \multicolumn{3}{|c|}{ Station 3} & \multicolumn{3}{|c|}{ Station 4} \\
\hline & $\begin{array}{l}\text { \# of } \\
\text { Ind. }\end{array}$ & $\begin{array}{l}\text { Rank } \\
\text { by \# }\end{array}$ & $\begin{array}{l}\% \text { of } \\
\text { total }\end{array}$ & $\begin{array}{l}\text { \# of } \\
\text { Ind. }\end{array}$ & $\begin{array}{l}\text { Rank } \\
\text { by \# }\end{array}$ & $\begin{array}{l}\% \text { of } \\
\text { total }\end{array}$ & $\begin{array}{l}\text { \# of } \\
\text { Ind. }\end{array}$ & $\begin{array}{l}\text { Rank } \\
\text { by \# }\end{array}$ & $\begin{array}{l}\% \text { of } \\
\text { total }\end{array}$ & $\begin{array}{l}\text { \# of } \\
\text { Ind. }\end{array}$ & $\begin{array}{l}\text { Rank } \\
\text { by \# }\end{array}$ & $\begin{array}{l}\% \text { of } \\
\text { total }\end{array}$ \\
\hline Cyathura polita $^{+\star}$ & 1 & 56 & 0.04 & 1 & 54 & 0.05 & & & & 26 & 6 & 1.54 \\
\hline Uca speciosa* & 1 & 57 & 0.04 & & & & & & & 15 & 8 & 0.89 \\
\hline tubellarian \#1 & 1 & 58 & 0.04 & 2 & 40 & 0.10 & 4 & 21 & 0.29 & 3 & 22 & 0.18 \\
\hline midge adult & 1 & 59 & 0.04 & 1 & 55 & 0.05 & 2 & 33 & 0.15 & 1 & 34 & 0.06 \\
\hline Malanidae gen. sp. & 1 & 60 & 0.04 & & & & 2 & 34 & 0.15 & 1 & 35 & 0.06 \\
\hline Geukensia demissa & 1 & 61 & 0.04 & 2 & 39 & 0.10 & & & & & & \\
\hline brachyuran megalopa & 1 & 62 & 0.04 & 1 & 56 & 0.05 & & & & & & \\
\hline spider & 1 & 63 & 0.04 & & & & & & & 1 & 36 & 0.06 \\
\hline hydrold colony & 1 & 64 & 0.04 & 1 & 57 & 0.05 & & & & & & \\
\hline Cerithidea costata ${ }^{\star}$ & 1 & 65 & 0.04 & 1 & 58 & 0.05 & & & & & & \\
\hline cirratulid gen. sp. & 1 & 66 & 0.04 & 1 & 59 & 0.05 & & & & & & \\
\hline sipunculid \#1 & 1 & 67 & 0.04 & & & & & & & 1 & 37 & 0.06 \\
\hline Ensis minor ${ }^{+}$ & 1 & 68 & 0.04 & & & & & & & & & \\
\hline Onobops sp. & 1 & 69 & 0.04 & & & & & & & & & \\
\hline venerid clam & 1 & 70 & 0.04 & & & & & & & & & \\
\hline Sigalionidae gen. sp. & 1 & 71 & 0.04 & & & & & & & & & \\
\hline Bowmaniella dissimilis ${ }^{+}$ & 1 & 72 & 0.04 & & & & & & & & & \\
\hline Eurypanopeus depressus & 1 & 73 & 0.04 & & & & & & & & & \\
\hline Mysidopsis $s p$ & 1 & 74 & 0.04 & & & & & & & & & \\
\hline Hesionidae gen. sp. & 1 & 75 & 0.04 & & & & & & & & & \\
\hline Bougainvillia sp. & 1 & 76 & 0.04 & & & & & & & & & \\
\hline turbellarlan \#3 & 1 & 77 & 0.04 & & & & & & & & & \\
\hline turbellarian \#4 & 1 & 78 & 0.04 & & & & & & & & & \\
\hline Heleobops sp. & & & & 49 & 11 & 2.54 & 3 & 26 & 0.22 & & & \\
\hline Cyrenoidea floridana* & & & & & & & & & & 11 & 9 & 0.58 \\
\hline Namalycastis abiuma & & & & & & & & & & 11 & 10 & 0.58 \\
\hline midge larvae & & & & & & & 2 & 35 & 0.15 & 7 & 15 & 0.37 \\
\hline kinorhynch & & & & 7 & 27 & 0.36 & 2 & 36 & 0.15 & & & \\
\hline Polymesoda caroliniana* & & & & & & & 1 & 45 & 0.07 & 5 & 17 & 0.27 \\
\hline Talitridae gen. sp. & & & & & & & & & & 5 & 18 & 0.27 \\
\hline Littrodinops palustres* & & & & 3 & 35 & 0.16 & 1 & 46 & 0.07 & & & \\
\hline bivalve \#1 & & & & 4 & 33 & 0.21 & & & & & & \\
\hline Lepismidae larvae & & & & 1 & 60 & 0.05 & & & & 1 & 38 & 0.05 \\
\hline hydroid & & & & 2 & 41 & 0.10 & & & & & & \\
\hline bivalve \#2 & & & & 2 & 42 & 0.10 & & & & & & \\
\hline Ceratonereis irritab/is & & & & 1 & 61 & 0.05 & 1 & 47 & 0.07 & & & \\
\hline Prionospio heterobranchia ${ }^{+}$ & & & & 2 & 43 & 0.10 & & & & & & \\
\hline Corophium louislanum ${ }^{+\star}$ & & & & & & & 1 & 48 & 0.07 & & & \\
\hline Melita $s p .^{+\star}$ & & & & 1 & 66 & 0.05 & & & & & & \\
\hline Talorchestia sp. & & & & & & & & & & 1 & 39 & 0.05 \\
\hline bibionidae larvae & & & & & & & & & & 1 & 40 & 0.05 \\
\hline bryozoan & & & & & & & 1 & 49 & 0.07 & & & \\
\hline anthozoan & & & & & & & 1 & 50 & 0.07 & & & \\
\hline Hydractinia sp. & & & & & & & 1 & 51 & 0.07 & & & \\
\hline Epitonium rupicolum ${ }^{4}$ & & & & & & & & & & 1 & 41 & 0.05 \\
\hline Hydrobia sp. & & & & & & & & & & 1 & 42 & 0.05 \\
\hline limpet & & & & & & & 1 & 52 & 0.07 & & & \\
\hline Mactra tragilis* & & & & & & & & & & 1 & 43 & 0.05 \\
\hline Amphinoidae gen. sp. & & & & 1 & 62 & 0.05 & & & & & & \\
\hline Arenicola cristata $^{+}$ & & & & & & & 1 & 53 & 0.07 & & & \\
\hline Glycera dibranchiata & & & & & & & 1 & 54 & 0.07 & & & \\
\hline Loandalia americana $^{+}$ & & & & 1 & 63 & 0.05 & & & & & & \\
\hline Prinospio steenstropi & & & & 1 & 69 & 0.05 & & & & & & \\
\hline Spio sp. & & & & 1 & 65 & 0.05 & & & & & & \\
\hline Uca panacea & & & & & & & & & & 1 & 44 & 0.50 \\
\hline Totals & 2,602 & & & 1,924 & & & ,362 & & &, 691 & & \\
\hline
\end{tabular}


Table 1. Continued.

\begin{tabular}{lcrrrrrrr} 
Species & \multicolumn{2}{c}{ Station 1 } & \multicolumn{2}{c}{ Station 2 } & Station 3 & \multicolumn{2}{c}{ Station 4 } \\
\hline & $\begin{array}{l}\text { \# of } \\
\text { species }\end{array}$ & \multicolumn{1}{c}{$\%$} & $\begin{array}{c}\text { \# of } \\
\text { species }\end{array}$ & $\%$ & $\begin{array}{c}\text { \# of } \\
\text { specles }\end{array}$ & \multicolumn{1}{c}{$\begin{array}{c}\text { \# of } \\
\text { species }\end{array}$} & $\%$ \\
\hline Stream only & 34 & 52.3 & 20 & 38.5 & 16 & 40.0 & 17 & 45.9 \\
Marsh type & 5 & 7.7 & 7 & 13.5 & 6 & 15.0 & 5 & 13.5 \\
Estuary type & 18 & 27.7 & 17 & 32.7 & 11 & 27.5 & 9 & 24.3 \\
Marsh \& Estuary & 8 & 12.3 & 8 & 15.4 & 7 & 17.5 & 6 & 16.2 \\
\hline
\end{tabular}

+ Denotes estuarine species (Livingston et al., 1976).

* Denotes Marsh species (Subrahmanyam et al., 1976).

\# Denotes number of individuals times 89 gives $\# / \mathrm{m}^{2}$.

spatial variations in $\mathrm{H}^{\prime}$ values among the four stations throughout the sampling period (Figure 2). The highest $H^{\prime}$ value was 3.06 in June at station 1 , and the lowest was 0.57 in August at station 3. The highest monthly $\mathrm{H}^{\prime}$ of all four stations was 2.49 from June and the lowest was 1.48 in May. Differences in $H^{\prime}$ values were found to be significant (ANOVA, $\mathrm{p}<0.01$ ). Station 1 was significantly different from stations 3 and 4 but not from station 2; and stations 2, 3 and 4 were not significantly different from one another (DNMRT, $p<0.05$ ).

Faunal similarity analyses showed that stations 2, 3 and 4 were not significantly different from one another and stations 1 and 4 showed the least affinity (Table 2). In general adjoining stations were more similar to one another than non-adjoining stations, and the degree of similarity decreased as the distance between stations increased. Also, with the exception of the stations 2-3 comparison, the degree of similarity between stations tended to be the lowest in spring and highest during late summer or early fall.

\section{DISCUSSION}

There are few studies of salt marsh benthic invertebrate communities in the literature, however, the infaunal macroinvertebrates of the salt marsh at St. Marks are well known (Subrahmanyam et al., 1976; and Subrahmanyam and Coultas, 1980). A $26 \%$ species similarity was found between the tidal creek and the St. Marks marsh, after discounting incompletely identified organisms. Also, a $33 \%$ species similarity was noted between the creek and some northeastern Gulf of Mexico tidal marshes (Heard,

Table 2. Morisita Index Station to Station Comparison.

\begin{tabular}{ccccccc}
\hline $\begin{array}{c}\text { Month } \\
\text { Sampled }\end{array}$ & $\begin{array}{c}\text { Station } \\
1-2\end{array}$ & $\begin{array}{c}\text { Stations } \\
1-3\end{array}$ & $\begin{array}{c}\text { Stations } \\
1-4\end{array}$ & $\begin{array}{c}\text { Stations } \\
2-3\end{array}$ & $\begin{array}{c}\text { Stations } \\
2-4\end{array}$ & $\begin{array}{c}\text { Stations } \\
3-4\end{array}$ \\
\hline M & 0.0361 & 0.0093 & 0.0507 & 0.0561 & 0.0526 & 0.0363 \\
A & 0.0722 & 0.1080 & 0.0492 & 0.9161 & 0.2493 & 0.2607 \\
M & 0.0694 & 0.0697 & 0.0411 & 0.9773 & 0.9775 & 0.0581 \\
J & 0.3800 & 0.2584 & 0.1858 & 0.4130 & 0.1458 & 0.0196 \\
J & 0.5540 & 0.0268 & 0.0370 & 0.2280 & 0.5355 & 0.3534 \\
A & 0.6860 & 0.2338 & 0.1844 & 0.4773 & 0.4665 & 0.6019 \\
S & 0.7925 & 0.4970 & 0.1794 & 0.8731 & 0.8138 & 0.6750 \\
O & 0.9356 & 0.8637 & 0.1619 & 0.9590 & 0.1647 & 0.0602 \\
N & 0.1978 & 0.2613 & 0.0437 & 0.7559 & 0.1568 & 0.4030 \\
D & 0.1708 & 0.3846 & 0.2429 & 0.4390 & 0.1779 & 0.6252 \\
Monthly & & & & & & \\
Average & 0.3894 & 0.2709 & 0.1176 & 0.6095 & 0.2830 & 0.3093 \\
\hline
\end{tabular}



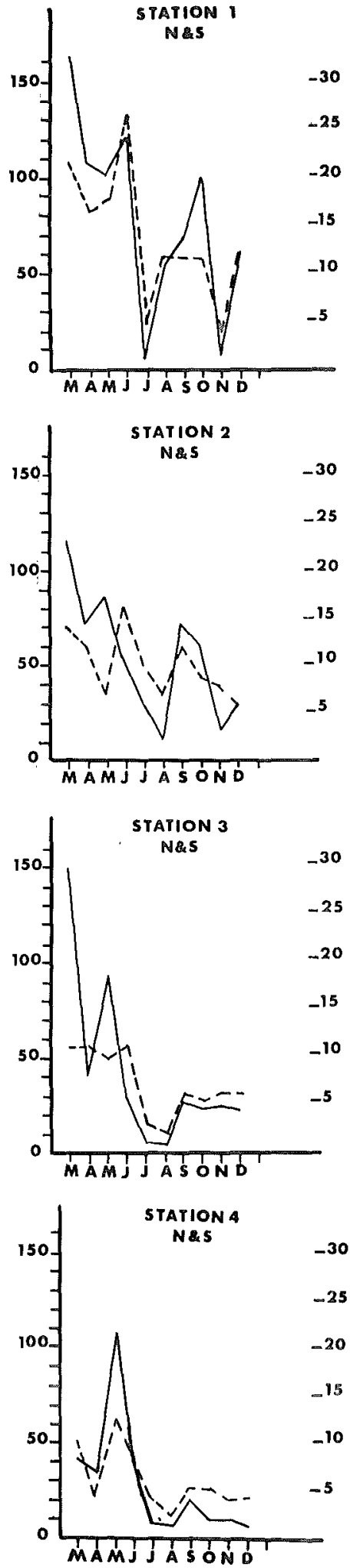
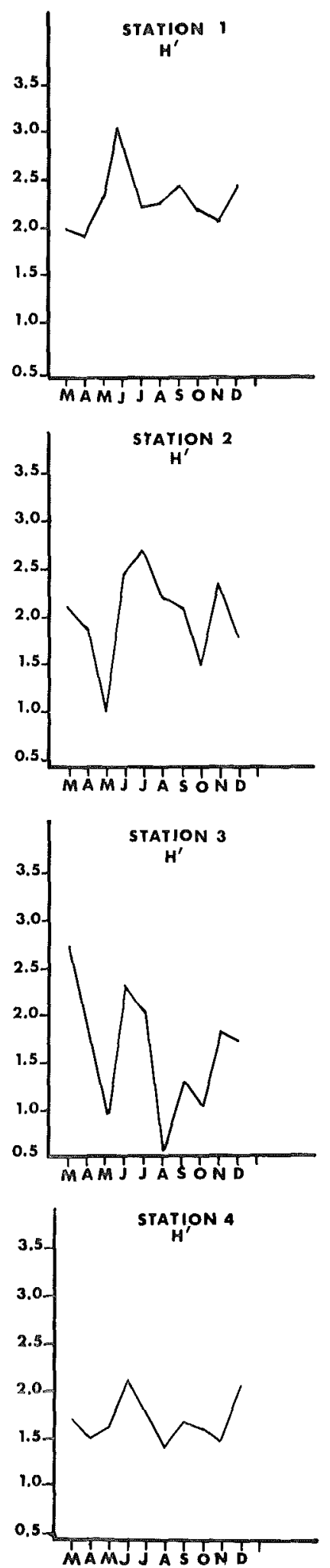

Figure 2. Seasonal fluctuations of observed species density $(\mathrm{N})$ (multiply by 89 to get density/ $\mathrm{m}^{2}$ ), solid line left hand scale; number of species (S), dashed line right hand scale; and Shannon-Weaver $(\mathrm{H})$. 
1982). The tidal creek species were also compared to those of Apalachicola Bay (Livingston, 1976), a well studied estuary approximately $50 \mathrm{~km}$ west of the St. Marks estuary. Forty five percent of the creek species were found to occur in Apalachicola Bay. The total species listed by Subrahmanyam et al. (1976) and Livingston (1976) accounted for $61 \%$ of creek species; a figure less than the total of the two studies which was due to an overlap of species occurence between the St. Marks marsh and the Apalachicola Bay. A remainder of $39 \%$ of the creek species were found neither in the St. Marks marsh nor in the Apalachicola Bay.

Comparisons of the macroinvertebrates infauna of the four individual tidal creek stations with that of nearby Apalachicola bay (Livingston, 1976) and the St. Marks marsh areas (Subrahmanyam et al., 1976) were made. The four most abundant species found during this study, listed one to four respectively, were hydrobid sp. 1, Laeonereis culveri, Hargaria rapax and Ampelisca abdita. These species were also the most abundant species at stations 3,2,4 and 1 respectively, the first and third species being found only in the creek and the remaining two species at estuary, creek and marsh locations. Approximately one quarter of the species at each creek station were also observed by Livingston (1976) in Apalachicola Bay but not by Subrahmanyam et al. (1976) in the salt marsh adjoining the creek. The percentages of those species indigenous to the marsh environment varied, however, from $3 \%$ at station 1 to $11 \%$ at station 4 (Table 1). When only the important species at the tidal creek were considered $48 \%, 23 \%, 23 \%$ and $20 \%$ of these species, from stations one to four respectively, were also found exclusively among estuarine fauna (Livingston, https://aquila.usm.edu/goms/vol6/iss2/1
1976). The marsh communities (Subrahmanyam et al. 1976), however, had a $5 \%, 15 \%, 8 \%$ and $0 \%$ species similarity to those of creek stations one to four respectively while those important creek species that were found in both the estuary and marsh accounted for $24 \%$, $15 \%, 15 \%$ and $60 \%$ of species at these same stations. Therefore, $23 \%, 47 \%$, $54 \%$, and $20 \%$ of the important species at stations one to four respectively did not occur either in the marsh or the estuary.

These patterns of species numbers and species abundances indicate overall that the estuarine species have greater representation in the creek than the marsh species, but with an observable spatial gradient of importance. The greatest abundance of estuarine species was noticed at station 1 and it decreased towards station 4. For the marsh species, on the other hand, this pattern was reversed as more marsh type species occurred at station 4 and fewer at station 1. There was a large group of species that occurred in the tidal creek which was absent both in the marsh and in the estuary. This group of species also made up a great percentage of the faunal density of the creek especially at stations 2 and 3 . These species are most likely the inhabitants of the intertidal mud flats located in front of the marsh. These mud flats were not investigated either by Livingston (1976) or by Subrahmanyam et al. (1976).

Seasonal changes in density or in the number of species were not found to be statistically significant at the St. Marks marsh (Subrahmanyam et al., 1976). Fluctuating seasonal abundance patterns, on the other hand, are characteristics of dynamic estuarine communities (Orth, 1973; Subrahmanyam et al., 1976; Livingston, 1976; Whitlatch, 1977). Tidal creeks/like 
estuaries, have been shown to exhibit marked seasonal changes in species composition (Hackney and Burbanck, 1976; Hackney et al., 1976; and Hackney and de la Cruz, 1981). The tidal creek at St. Marks also has shown significant seasonal numerical density and species fluctuations (ANOVA, $p<0.05$ ), with peaks both in spring and fall, which were similar at all tidal creek stations (Figure 2). These changes can be related to known patterns of breeding and recruitment which have been observed in areas similar to the St. Marks marsh and estuary (Nixon and Oviatt, 1973; Livingston, 1976; and Subrahmanyma and Coultas, 1980). Also, uniform midsummer declines in density were most likely related to increased numbers of predatory fish using the tidal creeks during these months (Subrahmanyam and Drake, 1975; and Subrahmanyam and Coultas, 1980).

Morisita's Index of affinity showed neighboring stations to be more similar faunistically than ones further apart. This likeness was found to increase during the late summer months when Hargaria rapax, Laeonereis culveri and other important species, which were common to all four stations, had large increases in abundance.

The tidal creek was found to have a lower average Shannon Weaver $\mathrm{H}^{\prime}$ value (1.9) than did the St. Marks marsh (2.5); diversity values were not available from estuarine studies for comparison. Salt marshes, areas generally regarded to have harsh physical environment (Brown, 1981), may have a more stable iden. tifiable community structure (Boesch, 1972) than that of the tidal creek. The creek has shown lower average $H^{\prime}$ values at stations 3 and 4 than at stations 1 and 2. This break in $\mathrm{H}^{\prime}$ may indicate an area of transition from a more stable marsh community to a more stable estuarine community. The $H^{\prime}$ values at all four tidal creek stations showed significant seasonal variations as did $\mathrm{H}^{\prime}$ values from the St. Marks and Wakulla marshes (Subrahmanyam et al., 1976). All curves, although not strictly parallel, showed an early spring depression, spring gain, summer depression, late summer gain, and fall depression. Although similar curves were produced at each station, they were not necessarily spatially synchronous and their differences were found to be significant.

The creek which we studied was short, approximately $300 \mathrm{~m}$, yet stations set at $100 \mathrm{~m}$ intervals proved to have different faunal composition. Gradients of species and numerical density and species diversity were shown to exist which increased towards the mouth of the creek during most of the study period. Based on these gradients, the faunal assemblage at the creek mouth was found to most resemble an estuarine community and that toward the creek origin was found to be more similar to that of the marsh community. This would warrant describing the tidal creek as an ecotone between the vegetated tidal marsh and the open water river mouth estuary. However, the large numbers of species which were not found in either the St. Mark's marsh (Subrahmanyam et al., 1976) or in a nearby estuary (Livingston, 1976) would indicate a need for further investigation including the study of nearby intertidal areas such as mudflats and sandbars.

\section{ACKNOWLEDGMENTS}

This study was supported by the U.S. Department of Agriculture, Scien. tific and Education/Cooperative Research grant N. 3801-15-14B. We thank Dr. William L. Kruczynski, formerly of the Salt Marsh Ecology Program, for his as- 
sistance in the collection of the tidal creek samples.

\section{LITERATURE CITED}

Basharin, G.P., 1969. On a statistical estimate for the entropy of a sequence of independent random variables. In: W. Artin, ed. Theory of probability and its applications (Translation of Theoriza Verovatnosei i ee primeniya) 4. Society for Industrial and Applied Mathematics, Philadelphia. 333-336

Boesch, D.F., 1972. Species diversity of marine macrobenthos in the Virginia area. Chesapeake Sci. 13: 206-211.

Brown, J.H., 1981. Two decades of homage to Santa Rosalia: Toward a general theory of diversity. American Zoologist. 21(4): 877-888.

Cruz, A.A. de la, 1973. The role of tidal marshes in the productivity of coastal waters. Assoc. Southeastern Biologist Bull. 20: 147-156.

Eleuterius, L.N., 1976. The distribution of Juncus roemerianus in the salt marshes of North America. Chesapeake Sci. 17(4): 289-292.

Hackney, C.T., and W.D. Burbanck, 1976. Some observations on the movement and location of juvenile shrimp in coastal waters of Georgia. Bulletin of Georgia Academy of Science 34: 129-136.

and A.A. de la Cruz, 1978.

The Fauna of a Mississippi, U.S.A. tical creek. J. Miss. Acad. Sci. 22 p. (Suppl.) 1979. Patterns of suspended particle transport in a Mississippi tidal marsh system. Gulf Research Reports 6: 217-224. , 1981. Some notes on the macrofauna of an oligohaline tidal creek in Mississippi. Bull. Mar. Sci. 31: 658-661.

and W.D. Burbanck and

O.P. Hackney, 1976. Biological and https://aquila.usm.edu/goms/vol6/iss2/1 physical dynamics of a Georgia tidal creek. Chesapeake Sci. 17(4): 271-280. Heard, R.W., 1982. Guide to common tidal marsh invertebrates of the Northeastern Gulf of Mexico. Report MASGP - 79-004, Mississippi-Alabama Sea Grant Consortium, Ocean Springs, MS. $82 \mathrm{p}$.

Homer, M., 1977. Seasonal abundance, biomass diversity, and trophic structure of fish in a salt marsh tidal creek affected by a coastal power plant. Pages 259-267, In: H.T. Odum, (ed.) Thermal Ecology II. University of Florida, Gainesville, Florida.

Livingston, R.J., 1976. Diurnal and seasonal fluctuations of organisms in a north Florida estuary. Estuarine and Coastal Mar. Sci. 4(4): 373-400.

Morisita, M., 1959. Measuring of interspecific association and similarity between communities. Mem. Fac. Sci. Kyushu Univ. 3: 65-80.

Nixon, S.W., and C.A. Oviatt, 1973. Ecology of a New England salt marsh. Ecolog. Monogr. 43: 463-498.

Orth, R.J., 1973. Benthic infauna of eelgrass, Zostera marina, beds. Chesapeake Science 14: 258-269.

Pickral, J.C., and W.E. Odum, 1976. Benthic detritus in a salt marsh tidal creek. pp. 280-292. In: M. Wiley (ed.), Estuarine Processes Vol. II. Academic Press, New York.

Sanders, H.L., 1960. Benthic studies in Buzzards Bay. III. The structure of the softbottom community. Limnol. Oceangr. 5: 138-153.

Settlemyre, J.L., and L.R. Gardner, 1975. A field study of chemical budgets for a small tidal creek-Charleston Harbor, S.C. American Chemical Society Symposium Series No. 18: 152-175.

Steel, R.G.D., and J.H. Torrie, 1960. Principles and procedures of statistics. McGraw-Hill Book Co., Inc., New York. $481 \mathrm{p}$. 
Subrahmanyam, C.B., and S.H. Drake, 1975. Studies on the animal communities in two north Florida salt marshes. Part I. Fish communities. Bull. Mar. Sci. 25:445-465. , and C.L. Coultas, 1980.

Studies on the animal communities in two north Florida salt marshes. Part III. Seasonal fluctuations of fish and macroinvertebrate communities. Bull. Mar. Sci. 30: 790-818.

W.L. Kruczynski, and

S.H. Drake, 1976. Studies on the animal communities in two north Florida salt marshes. Part II. Macroinvertebrate communities. Bull. Mar. Sci. 26: 172-195. , and C.L. Coultas, 1980. Studies on the animal com. munities in two north Florida salt marshes. Part III. Seasonal fluctuations of fish and macroinvertebrate communities. Bull. Mar. Sci. 30: 790-818.

W.L. Kruczynski, and S.H. Drake, 1976. Studies on the animal communities in two north Florida salt marshes. Part II. Macroinvertebrate communities. Bull. Mar. Sci. 26:172-195.

Teal, J.M., 1962. Energy flow in the salt marsh ecosystem of Georgia. Ecology 43: 614-624.

Weinstein, M.P., S.L. Weiss, and M.F. Walters, 1980. Multiple determinants of community structure in shallow marsh habitats, Cape Fear River estuary, North Carolina, U.S.A. Marine Biology 58: 227-243.

Whrtlatch, R.B., 1977. Seasonal changes in the community structure of the macrobenthos inhabiting the intertidal sand and mud flats of Barnstable Harbor, Massachusetts. Biological Bulletin 152: 275-294. 